\title{
Sepulchral Representation: Inscribed Tombs and Narrated Epitaphs in the High Middle Ages
}

Compared with other cultural techniques of memoria, the tomb's distinctive feature is its metonymic form of representation. As a sign it is always locally bound to what it designates; it indicates the proximity of what it stands for. Thus, its symbolic nature oscillates between the necessary absence and suggestive visualisation of the dead body: the tomb stands where the subject is no longer. This process of representation can be supported by various rhetorical strategies. They include the "epitaphic voice" in the first person (prosopopoeia) and deictic expressions, such as the prominent sepulchral formula hic situs est, both of which create the illusion that they establish physical contact with the past. ${ }^{1}$ Hence, the tomb belongs to the semiotic paradigm of quid pro quo, aiming to make the deceased appear spatially present.

Semiotic manifestations of tombs are undoubtedly historically variable. ${ }^{2}$ Starting in the tenth century, there was a gradual change in the way death was dealt with, which is reflected in the tombs designed for spiritual and secular princes, and can be described as an increasing need for individualisation. ${ }^{3}$ This trend includes the development of tomb sculptures from flat carved images to life-size sculptures and the "return" of tomb inscriptions. ${ }^{4}$ In the early Middle Ages, nameless tombs had largely been the norm. Then, between the tenth and twelfth centuries, epitaphs began to contain short identifications, primarily the deceased's name, state and date of death. While epitaphs of the high Middle Ages could sometimes also contain a prayer for the soul of the deceased, it was not until the thirteenth and fourteenth centuries that epitaphs increasingly gained scope and eloquence. ${ }^{5}$

\footnotetext{
1 Newstock has even described deixis as "the principal declaration of an epitaph", see Newstok 2009, 1. 2 Basic information on the development of tombs in the Middle Ages has been provided by Panofsky 1964; Bauch 1976; Ariès 2009; Kloos 1980, 70-79; Petrucci 1995; Körner 1997.

3 The burial in the church proper was generally limited to dignitaries (bishops, auxiliary bishops, provosts, deans, abbots and priors) (see Kloos 1980, 71). For sovereigns and high nobility a funeral in the church was regulated by the patronage law, to which the ius sepulturae belonged; the ministerial nobility and the patrician bourgeoisie, on the other hand, could only obtain a funeral by the foundation of a chapel or an altar with the pertinent benefices (see ibid., 72).

4 See Ariès 2009, 278.

5 Ariès 2009, 280. Epitaphs on tombs are distinguished from memorials (likewise called epitaphs) emerging since the fourteenth century onwards, that were added to the tomb slab, which was executed as a tomb, but later also served only as a memorial for the deceased.
}

This publication originated in the Collaborative Research Centre 933 "Material Text Cultures. Materiality and Presence of Writing in Non-Typographic Societies" (subproject C05 “Inscriptionality. Reflections of Material Text Culture in the Literature of the 12th to 17th Centuries"). The CRC 933 is funded by the German Research Foundation (DFG).

Ә Open Access. (c) 2019 Laura Velte, published by De Gruyter. (c) BY-NC-ND This work is licensed under the Creative Commons Attribution-NonCommercial-NoDerivatives 4.0 License. 
The dissemination of sepulchral as well as other inscriptions correlates with the progressive rise of literacy in Europe, which was driven by the aristocratic courts and gradually spread to the cities, where the new necessity for literacy informed lay schools and administrative apparatuses. It is therefore no coincidence that between the twelfth and thirteenth centuries, historiography and literature began to reflect on the social functions and semiotic modes of sepulchral representation, placing tombs at the centre of an emerging discourse. In the following chapter, I shall concentrate on three pivotal examples from this time to address how they imagine the material designs of text and image on a monument in order to shape the commemoration of the dead: first, the monumental historical work Historia Ecclesiastica of the Norman Benedictine monk Orderic Vitalis (1075-c.1142), second, the Alexandreis by learned author Walter von Châtillon (c.1135-c.1190), and last, the German translation of the French Prose Lancelot (c. 1215-c.1230). These three texts were widely transmitted and broadly received during the Middle Ages and can therefore be considered representative of the contemporary sepulchral discourse.

Despite its fundamental focus on the past, ever since Isidore of Seville medieval historiography largely attaches importance to the present and, thus, to what can be empirically verifiable. In his Etymologiae, Isidore demands that historians should trust their own eyes rather than what has been told to them. ${ }^{6}$ Orderic Vitalis similarly commits himself to the task of recording personally experienced and observed events for later generations in his Historia Ecclesiastica: ${ }^{7}$

\begin{abstract}
Non arte litteratoria fultus, nec scientia nec facundia preditus: sed bonae uoluntatis intentione prouocatus appeto nunc dictare de his quae uidemus seu toleramus. Decet utique ut sicut nouae res mundo cotidie accidunt, sic ad laudem Dei assidue scripto tradantur, et sicut ab anterioribus preterita gesta usque ad nos transmissa sunt: sic etiam presentia nunc a presentibus futurae posteritati litterarum notamine transmittantur. (I, 130f., my emphasis)
\end{abstract}

Now, equipped with no literary skill to support me and endowed with neither knowledge nor eloquence, but inspired by the best intentions, I set about composing an account of the events which we witness and endure. It is fitting that, since new events take place every day in this world, they should be systematically committed to writing to the glory of God, so that-just as past deeds have been handed down by our forebears present happenings should be recorded now and passed on by the men of today to future generations.

6 See Isid. Etym. 1.41: Apud veteres enim nemo conscribebat historiam nisi is qui interfuisset, et ea quae conscribenda essent vidisset. Melius enim oculis quae fiunt deprehendimus, quam quae auditione colligimus.

7 Cited after Chibnall (ed.) 1980 (in the following cited as Hist. Eccl.). 
Despite the commitment, formulated in the preface, to keep the presentia central in his Historia Ecclesiastica, Orderic expands his history of the Benedictine abbey of St Évroul, initially ordered by Prior Roger (1096-1123), into successively wider contexts, producing a monumental history of the land and church of the Normans. Finally, he sets two books on the early history of the church at the beginning, describing all apostles, evangelists and the vitae of popes (apart from Leo IV), so that the continuously growing presentation corresponds more and more to a universal church history. A particular formal feature of his thirteen-volume historical work is the creation of narratives that also feature various embedded poetic additions. Among these are a total of 37 quoted epitaphs (referred to as carmen, versus, elogium, epilogum and often also as epitaphium), which begin in Book Four and noticeably accumulate in Books Five, Eight and Eleven. ${ }^{8}$ The epitaphs of the Historia Ecclesiastica are dedicated to both secular and ecclesiastical leaders and, apart from one exception, are written in the Elegiac Distichon or in Leonine Hexameter. A substantial part of the epitaphs (altogether 27) deal explicitly with inscriptions on gravestones. The others feature funeral poetry, which was possibly composed for the burial ceremony or the anniversary of the subject's death.

The first epitaph is found at the beginning of Book Four after the description of the coronation of William I as king of England (at the end of Book Three) and praise for the king's reforms and monastic foundations. In 1067, it is said that William spent Easter at the Benedictine abbey at La Trinité de Fécamp. The ceremony is led by Maurilius, archbishop of Rouen, who dies shortly thereafter. But instead of relaying the archbishop's historical significance for the cooperation of secular and ecclesiastical powers in the struggle for the reformation of the church, Orderic describes his gravestone at the Cathedral of Rouen. He cites the elegiac epitaph verbatim with a detailed statement about its author. The description gives a deictic reference to the church (hanc aedem), which Maurilius once consecrated and in which his body is now entombed:

\author{
Epitaphium autem eius a Ricardo Herluini filio \\ eiusdem aecclesiae canonico editum est. et su- \\ per ipsum in cupri laminis ex auro sic scriptum \\ est: \\ "Humani ciues lacrimam nolite negare \\ Vestro pontifici Maurilio monacho. \\ Hunc Remis genuit, studiorum Legia nutrix \\ Potauit trifido fonte philosophico. \\ Vobis hanc aedem ceptam perduxit ad unguem, \\ Laetitia magna fecit et encenia.
}

His epitaph was composed by Richard son of Herluin, canon of Rouen cathedral, and inscribed above his tomb in gold letters on bronze plates. It runs thus:

"O mortal men, do not deny a tear For Maurille, monk and bishop, buried here; Nurtured by Rheims and schooled by Liège, he Drank from the triple fount philosophy. For you this fair cathedral, new begun He raised, and gave glad benediction.

8 For a comprehensive discussion of all sources, please see my PhD Thesis (Sepulkralsemiotik, expected to be published in 2020). 
Cum tibi Laurenti uigilat plebs sobria Christi. Transit, et in coelis laurea festa colit."

(IV, 198f., my emphasis)
Then Laurence, on thy holy vigil, he Passed into heaven to keep thy feast with

thee."

The prominent break between prose and verse can be explained by the literary tradition of the high Middle Ages. In the twelfth century, grave poetry was a widespread phenomenon, which, apart from the inscription of gravestones and tomb slabs in monastic contexts, is particularly related to the circulation of mortuary rolls. ${ }^{9}$ In addition to influential northern French poets such as Baudri of Bourgueil or Fulcoius of Beauvais, of whom whole collections of epitaphs and epigrams are known, historians preceding and contemporaneous with Orderic made use of epigraphic implements: first and foremost Bede, who is mentioned by Orderic in the preface of his first book as role model. ${ }^{10}$ The history of the Normans by annalist Dudo of Saint-Quentin is also distinguished by a prosimetrical style of composition. ${ }^{11}$ Likewise, the Anglo-Norman historian Henry of Huntingdon (c. 1088-1157) added nine epitaphs to his Historia Anglorum, eight of which are attributed to his own writing. ${ }^{12}$

Unlike these named historical works, epitaphs in the Historia Ecclesiastica are not merely used to emphatically praise particular figures of the past but rather are important features in Orderic's visualisation program. Already the fact that epitaphs are only first featured in Book Four (which reports events starting in 1067) and increase in the following Book Five (which coincides with the year of Orderic's birth, 1075), ${ }^{13}$ suggests that Orderic concentrates completely on the memoria of the dead from his own time. In addition, the amount of epitaphic parentheses in Orderic's text in comparison to his predecessors and contemporaries is drastically different. It seems that Orderic wishes thereby to provide a comprehensive "collection of sources" of his own time for his future readers.

9 Mortuary rolls came up in the ninth century. They circulated between Benedictine monasteries containing notices (encyclica) of the deaths of clergy and were successively extended. Personal sympathy could be expressed in the form of tituli. Some of the rolls reached astonishing proportions. The roll of abbess Mathilda of the Benedictine abbey of St Trinite of Caen (died 1113), for example, is 20 metres long, see Signori 2014, 7. An edition of mortuary rolls has been provided by Dufour (ed.) 2005-2013.

10 Bede's Historia Ecclesiastica gentis Anglorum cites a total of five epitaphs. Two of these are for Pope Gregory the Great and Augustine of Canterbury, both of whom are assumed to have spread Roman Catholic Christianity in southern England. A further epitaph for Caedwalla, King of Wessex is mentioned, as is one for Bishop Theodor, of whose grave inscription (numbering 34 verses) only the first and the last four verses are mentioned. Finally, the epitaph of Bishop Wilfrid is mentioned, on whose death (similar to Gregory the Great) an extensive biographical review is provided, which is condensed in an epitaph featuring twenty verses.

11 On the poetic insertions in different historical works and the relationships between Dudo of St Quentin, William of Jumièges, Orderic Vitalis and Robert of Torigni see Pohl 2015, 225-240.

12 On the epitaphs in Henry of Huntingdon's Historia Anglorum see Kay 2013, 36-44. Kay assumes that the poems were created earlier and only later were added to the historical work.

13 The dates of Orderic's life are taken from the autobiographical entries in the Historia Ecclesiastica. 
The accuracy of Orderic's gravestone descriptions attests to his role as a historian of his time. He meticulously analyses the use of materials (stone, bronze, gold, gemstones, etc.), colours (the gravestones are partly painted) and forms (plates, bows, memorial, etc.) of each tomb, as well as giving precise information on spatial locations. In a number of instances, he specifies a gravestone's condition at the present, thus clearly announcing his role as a contemporary eyewitness. This is particularly the case with graves at or around St Évroul, such as the description of the grave of Robert of Rhuddlan, whose bones were moved to St Évroul through his brother's efforts. Orderic composed the exceptionally long epitaph (44 verses) himself:

Eiusque studio conditus super tumulum fratris sui lapideus arcus usque hodie consistit. Rainaldus pictor cognomento Bartholomeus uariis coloribus arcum tumulumque depinxit. et Vitalis angligena satis ab Ernaldo rogatus epitaphium elegiacis uersibus hoc modo edidit.

"Hoc in mausoleo Robertus de Rodelento Conditur humano more soli gremio [...]." (VIII, 142ff., my emphasis)
Thanks to his endeavours a stone arch was erected over the tomb of his brother, where it stands to this day. Reginald called Bartholomew, a painter, painted the arch and tomb in different colours, and the Englishman Vitalis, at Arnold's earnest request, composed this epitaph in elegiac verse:

"Here in this tomb Robert of Rhuddlan lies $[\ldots]$...

In the description of the gravestone of Matilda, Queen of England, however, the date of death in the narrator's commentary differs from the actual epitaph:

[...] [Mathildis regina Anglorum] iii $^{\circ}$ non' Nouembris obiit. Deinde corpus eius ad coenobium sanctae Trinitatis quod ipsa sanctimonialibus apud Cadomum construxerat delatum est. et ab episcopis ac abbatibus multis inter chorum et altare uenerabiliter tumulatum est. [...] Memoriale eius super ipsam ex auro et gemmis mirifice constructum est. et epitaphium huiusmodi litteris aureis comiter exaratum est.

"Egregie pulchri tegit haec structura sepulchri, Moribus insignem germen regale Mathildem.

[...] Sic infinitae petiit consortia uitae, In prima mensis post primam luce

Novembris."
[...] [Matilda, queen of England] died on 3 November. Her body was carried at once to the abbey of the Holy Trinity, which she had founded at Caen for nuns, and was reverently buried by many bishops and abbots between the choir and the altar. [...] A monument was erected over her, wonderfully worked with gold and precious stones, and this epitaph was lovingly engraved in letters of gold:

"The lofty structure of this splendid tomb Hides great Matilda, sprung from royal stem; [...] At daybreak on November's second day She won her share of everlasting joy."

(VII, 44, my emphasis)

While the introduction mentions that Matilda died on November 3rd, the epitaph correctly dates her death to November 2nd. It is possible that Matilda's day of remembrance was set at St Évroul on November third. ${ }^{14}$ But it is still remarkable that despite the discrepancy a correct citation was given in the epitaph. Thus, the tomb inscription

14 See Hist. Eccl., VII, 44 and Comment 3. 
as cited by Orderic still matches the wording of the real inscription on the gravestone, which can be visited to this day at the Norman monastic church Sainte-Trinité in Caen.

Apart from proving Orderic's historical accuracy, epitaphs clearly act as 'texts within a text' in terms of manuscript layout. Three autographs of the Historia Ecclesiastica, which are stored today in the Bibliothèque nationale de France, indicate that a marker on the textual surface was indeed intended..$^{15}$ The autographs are distinguished by intensive marginal glossing, which in most cases feature summaries of the main text. ${ }^{16}$ Additionally, initials of different sizes act as markers of units of meaning. An examination of them demonstrates that cited epitaphs fulfil a clear segmentation function on the textual surface for the autobiographical Books Three to Six. Regardless if they are mentioned on gravestones or noted otherwise, all cited tomb inscriptions are highlighted in the manuscripts through initials at the beginning of a verse, marginalia and/or are emphasised by a lavish ragged margin. ${ }^{17}$

Epitaphs are not only distinguished from the justified, continuing prose text through (mostly vertically) arranged initials on the left (or, in Elegiac Distichon, by the hanging pentameter). They are also marked as poetical insertions at the border of the page with the indication epitaphium/epita ${ }^{m} /$ epi $^{m}+$ name (+ standing/origin/ monastic affiliation) of the deceased. Once a verse begins in a new line, the right side features an open alignment, which visually supports the logic of the text. Even if a few of the epitaphs differ from this scheme and are put into the main text instead (possibly due to economic reasons), the verse initials and the gloss remain the same in these epitaphs. ${ }^{18}$ The rhythmic and generic break is thus also accompanied by a visual turning point, which supports the increased visibility of the epitaphs. In such a way, the scribal tradition can contribute to the sensory experience of remembrance for those recipients that are spatially and temporally separated from the (initial) $m e$ moria of the dead.

According to Debiais and Ingrand-Varenne, the implementation of grave poetry initiates a change in the voice, adding a "polyphony" to the work. ${ }^{19}$ It should be noted, however, that this polyphony is carefully arranged, not only because the author has made a selection of poetic insertions in advance, but also because he has remarkably often cited his own poetry (of the thirty-seven grave inscriptions nine are self-citations). With a quarter of the "voices", Orderic thus also dominates the polyphony

15 The period of origin of the MSS. Lat. 5506 vol. 1 (books I and II) and vol. 2 (books III-VI), as well as 10913, are dated to the time between 1123 and 1141.

16 See Debiais/Ingrand-Varenne 2016, 139.

17 The following information refers to the named autographs and thus to the epitaphs in the books IV-VI and X-XIII.

18 This space-saving design is predominant in MS lat. 10913 (book X-XIII): Only two epitaphs are visually highlighted with a ragged margin. In both instances, clerics from the monastery of St Évroul are mentioned. Both were given grave inscriptions by Orderic himself. Also, the marginalia are in parts left out (not, however, in any of the poems composed by Orderic).

19 Debiais/Ingrand-Varenne 2016, 141. 


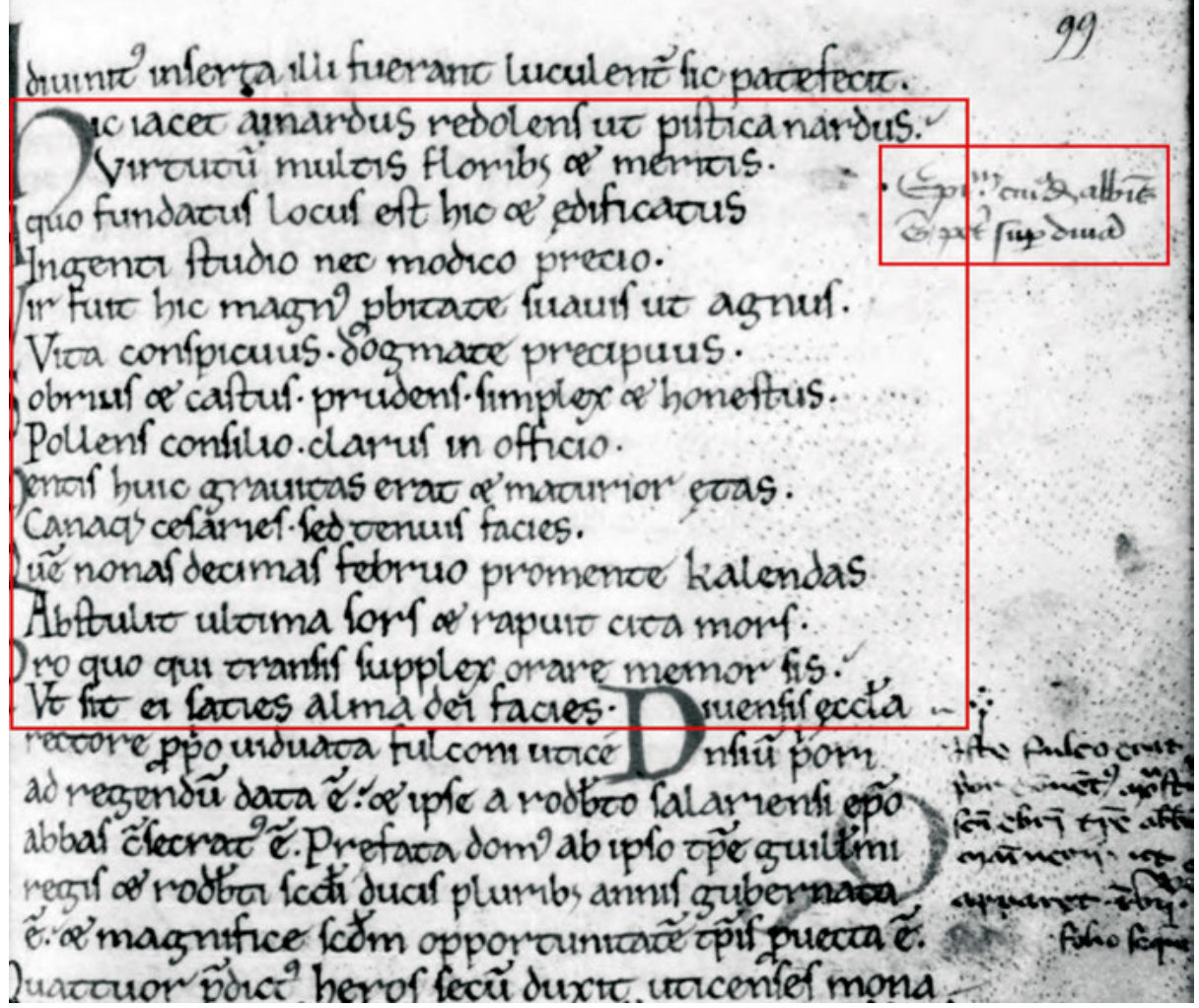

Fig. 1: Epitaph for the Abbot Ainard of Dive in Hist. Eccl. IV. Source: gallica.bnf.fr / Bibliothèque nationale de France, Ms. Latin 5506 (2), vue 100.

of these poetic passages. I would therefore assume that the insertions merely aim at underlining historical authenticity on the one hand, and at creating a certain kind of presentness on the other, which emerges both through the guided viewing and reading of the manuscript, as well as in rhythmic speaking and hearing. The description of sepulchral arrangements thereby let (extratextual) recipients and (intertextual) deceased persons enter into a close relationship for a short time, constituted by the suggestion of a spatial-material constant.

\section{II}

Detailed descriptions of sepulchral arrangements can also be found in literary texts, especially in medieval renarrations of ancient subject matter. The reappraisal of topics taken from antiquity goes hand in hand with the appropriation of ancient rhetorical forms of representation such as ekphrasis, the verbal representation of visual 
objects of art. Here a special attention is given to the material state of the world of things. Hermeneutic recognition and sensual experience are created as two possible modes of reception in the texts and are controlled by the commentary of an authorial narrator.

The great epic, Alexandreis, by Walter of Châtillon (c.1170) is here taken as an example, since it features several elaborately staged gravestones. ${ }^{20}$ The Alexandreis was passed down in over 175 manuscripts (half of which date to the twelfth and thirteenth centuries) and immediately received commentary. In only a few centuries, the Alexandreis was promoted to be read in schools and could even replace the classics of grammar instruction, Vergil and Lucan (whose epics are at the same time important subtexts to the Alexandreis). ${ }^{21}$ In the following, I will demonstrate that the detailed descriptions of heroes' graves reflect an epoch-specific chronotopos. The interlocking features of a hero's time and an eschatologically dimensional world time in the novel are made visible by way of these descriptions.

A total of four gravestones are described in the course of the narrative, in which the translatio imperii from the kingdom of Babylon to the Persians up to Hellenism is made visible. (1) In the first book, Alexander finds the grave of his heroic model Achilles (cf. 1, 468-538) whose inscription is phrased in the first person and in an archaic style. (2) In the fourth and seventh book, Alexander becomes himself a benefactor of two gravestones: first for the Persian Queen Stateira (cf. 4, 176-274), and then (3) for the fallen Persian King Darius (cf. 7, 379-430). The detailed descriptions of these two graves effect lengthy breaks in the story's events. ${ }^{22}$ Both graves are connected to a description of the shield of King Darius (cf. 2, 494-539), which depicts the story of the Persian people. The genealogy of the Babylonian-Persian rule is gradually expanded and completed through the descriptions of the gravestones of the royal couple. The transition from the shield to the gravestone indicates that the symbolic claim to power attached to the armaments of Darius can no longer hold without restriction. Instead, the description of the tombs thematically foregrounds the transition of sovereignty. At the same time, Old Testament motifs relate the graves to Daniel's prophecy of the four world empires, to which the epic refers repeatedly. ${ }^{23}$ In this way, the victory of Alexander over the Persians is placed into an eschatological perspective, and the proportions of the divine plan for salvation are laid before the characters-in almost a museal way-through picture and text. This happens in two steps: at first, the

20 More examples of tomb ekphrasis may be found in the vernacular romances of antiquity Le Roman d'Énéas, Le Roman de Troie by Benoît de Sainte-Maure, as well as in the many vernacular versions of the romance of Alexander. Two other important examples are given in the romantic story of Floire et Blancheflor and in Parzival by Wolfram von Eschenbach. For a comprehensive discussion of all these texts, please see my PhD Thesis.

21 See Killermann 2002, 299-331.

22 See Ratkowitsch 1991, on the ekphrasis passages in Châtillon, 129-211.

23 See Wulfram 2000, $253 \mathrm{ff}$. 
temporal expansion of the history of salvation is visualised at Stateira's gravestone, which depicts the happenings before the Persian rule (since the creation of the world out of chaos), and is placed in relation to the New Testament by quotations of Old Testament prophets. Then, the history of humankind is laid out spatially as a mappa mundi on the second gravestone of Darius. (4) Finally, Alexander's own tombstone is mentioned in the tenth book of the Alexandreis, which is given less space than the other gravestones and is neither embellished with scripture nor decorated.

The gravestones of Achilles and King Darius in the Alexandreis illustrate which medial and material techniques ensured posthumous fame. In contrast to the prosopopoietic epitaph of Achilles, the epitaph of Darius's grave specifically focusses on the extratextual recipient. The reader can interpret and capture the meaning of the depiction (that is the entanglement of temporal and spatial semantics) due to an advantage in knowledge, while the figures within the diegeses are dependent on their sensual experience. On arrival in Asia, Alexander starts to search for traces of heroic prehistory (1, 457: uetustatis saltim uestigia querit). As he walks, he reencounters the course of events in the Trojan War and thus creates in the reader's mind's eye the legendary foil by which his own claim to posthumous heroic fame is subsequently negotiated. At the edge of a river, he first encounters a poplar tree with words carved into its bark (though they are not cited directly). They recall the love of the Trojan prince Paris for the nymph Oenone in a peaceful time before the great war between Orient and Occident. ${ }^{24}$ Similar to a landmark, the poplar tree signals to Alexander that he has entered a historic landscape. He continues on his exploration and-from the forest-reaches the valley in which the judicial decision regarding Paris was made. From there, he arrives at the legendary ruined castle Ilions. After moving through several locations, Alexander reaches the former battlefield, which is dotted with heroes' graves. Only there, as he views the grave of Achilles, does the report become more detailed, bringing narrated and narrative time together. The grave of Achilles is the only one which features a directly cited inscription. The epitaph (epygrammata) is recounted by a first-person narrator, who even in death still claims heroic agency: ${ }^{25}$

Tot bellatorum Macedo dum busta pererrat Argolicos inter cineres manesque sepultos, Quos tamen accusant titulis epygrammata

$$
\text { certis, }
$$

Ecce minora loco quam fama uidit Achillis Forte sepulchra sui tali distincta sigillo:

"Hectoris Eacides domitor clam incautus

inermis

Occubui, Paridis traiectus arundine plantas.” (1, 468-474)
As thus the Macedonian slowly wandered among so many tombs of Argive warriors, their buried shades and ashes, whom inscriptions still gave their titles clearly carved, behold! He saw Achilles's tomb, of lesser breadth than fame, adorned with verses such as these: "Aeacus son Hectors slayer I fell unarmed unwary in a hidden spot pierced through the heel by Paris's stealthy dart."

24 For more on this inscription see "Inscriptions on Wood" in this volume.

25 Cited after Colker (ed.) 1978. All translations are taken from Townsend 1996. 
The grave mound of Achilles is so small and unremarkable that Alexander only finds it by accident (forte). Instead of a heroic memorial, rising from the mass of those fallen warriors buried before Troy, the mound of Achilles disappears inconspicuously in the Iliadic funerary landscape. Only the prosopopoietic inscription bears witness to the notorious wrath of the hero, the conqueror of Hector, who laments posthumously about his own disgraceful and treacherous murder. Achilles may have fallen, but due to the inscription's first-person narration, he is able to borrow the voices of the passers-by to ensure the continuation of his own memoria. ${ }^{26}$ Nevertheless, since Alexander only finds the grave incidentally-the grave as a material presence is hardly noticeable-the effectiveness of this strategy is questionable.

While the anecdote of Alexander's visit to the grave of Achilles was popular in antiquity (and late antiquity), it does not usually contain an epitaph. It featured, rather, a lament by the Macedonian king-also in the Alexandreis-about Achilles's good fortune that the great Homer recorded his heroic deeds and thus gave him eternal fame: ${ }^{27}$

[...] summum tamen illud honoris

Arbitror augmentum, quod tantum tantus

habere

Post obitum meruit preconem laudis Homerum.

O utinam nostros resoluto corpore tantis

Laudibus attollat non invidia fama tryumphos!

$(1,481-485)$
[...] and yet this is the highest increase to his honor-or so I judge-that such a man in death should merit such a herald of his praise as Homer. Would that Fame, unenvious, should sing, when we are dead, such songs of praise!

In Alexander's exclamation, the sparse epitaph is contrasted with the eternal glory of the hero in the Homeric Iliad. The visit to Troy and the lament at the grave of Achilles thus offer not only a review of bygone events, but also contemplate human limitations and strategies of perpetuation. In his dialogue with the Greek hero, to whom Alexander lends his voice, the king realises that a hero is always dependent on the memory of his progeny. The simplicity of the gravestone is not the actual focus, but rather Alexander's fear that there is no Homer to remember his deeds and that future generations may even regard them adversely. While a spatially-bound inscriptionthe materially solidified traces (uestigia) on wood and stone-may indeed protect and certify the memoria, an epically-transmitted fame (fama) can effectively disseminate and sublimate the deeds.

The character's discourse suggests that the narrator would like to be understood as a "second Homer", who is able to artfully present and elaborate the knowledge of the past. ${ }^{28}$ For medieval audiences, the two characters, Achilles and Alexander, belong to a heroic prehistory and have recently become part of cultural memory. Unaware of

26 For the implementation of classical first-person inscriptions, see Svenbro 1988.

27 See Cic. Pro Arch. 24, Hier. Vita S. Hilar. eremitae 1.1-4, PL 23, 29a, Hist. Aug. Vita Probi 1.2; at length on the motif of the heroic epitaph, see Castelain 2016, 109-130.

28 See Wulfram 2000, 235. 
his later fama and anxious about his posthumous legacy, Alexander's description creates a performative contradiction on the level of narration. After all, the story of Alexander's lament is embedded in a comprehensive medieval verse epic, which indeed remembers his deeds-but the character himself cannot know about this.

The other descriptions of graves in the Alexandreis differ from the first as they are extended to include detailed and visually appealing descriptiones for which no classical templates exist. After long-lasting military conflicts, the Persian King Darius is finally betrayed and killed by his own followers. Alexander, however, wishes to grant his nemesis his last request for perpetuation because, as he himself proclaims after he finds his fallen enemy in a ravine near to Ecbatana, the only one hope for luckless humans is that fame knows no death and a name can live on forever (cf. 7, 355-358). Darius's tomb, like Stateira's, is designed by the legendary sculptor Apelles. It is a pyramid of snow-white marble (7, 383: Pyramis [...] niueo que structa) whose exterior joints are elegantly concealed with lustrous red gold (cf. 7, $387 \mathrm{f}$.). Around the pyramid stand four pillars, partly made of gold and silver (cf. 7, 389-396), which carry a dome depicting the regions of Asia, Africa and Europe. The narrative recounts that the vault is more transparent than glass (7, 394: lucidior uitro), cleaner than calmed water (ibid.: pacato purior amne) and similar to a crystal (7, 395: Crystallo similis). At the same time, the whole earth with all its rivers, cities, mountains and the sea is represented on the vault (cf. 7, 398-403). All nations and peoples of the earth are portrayed, such as the ivory- and gemstone-rich India, Africa with its Carthaginian castle, Greece and Rome, as well as the Frankish realm with its great army and the famous wine of Champagne (cf. 7, 404-414). Then the narrator goes on to describe the three continents of the earth, organised as a T-O map: Asia, Europe and Africa are surrounded by the ocean, with the Mediterranean Sea forming a hinge between the three regions (cf. 7, 414-420). This gleaming dome also contains an inscription:

\begin{abstract}
Et quia non latuit sensus Danielis Apellem, Aurea signauit epigrammate marmora tali: "Hic situs est typicus aries, duo cornua cuius Fregit Alexander, totius malleus orbis.” Preterea Hebreos et eorum scripta secutus, Preteriti serie reuoluta temporis, annos Humani generis a condicione notauit Vsque triumphantis ad bellica tempora Magni. In summa annorum bis milia bina leguntur Bisque quadringenti decies sex bisque
\end{abstract}

$(7,421-430)$

\begin{abstract}
And since Apelles was not ignorant of Daniel's meaning, with this epigram he marked the stones: "Here lies the figured ram whose double horns Great Alexander broke hammer of all the world." Then, following the Hebrews and their Scriptures, he set down the years of humankind from its creation, how all the sequence of past times revolved until the warlike Great One's victories. The sum of years were read thus: twice two thousand, four hundred twice, six tens, and still twice four.
\end{abstract}

The question about a guarantee for earthly posthumous glory, which was first raised at the inconspicuous gravestone of Achilles, is taken up again and answered differently here, offering not a written tradition (a Homeric epic) but a magnificently composed "trace". With this architectonically striking monument Alexander wants to 
preserve the fama of his enemy (cf. 7, 358). While the exclusive and diaphanous materials, arranged in geometric patterns, sublimate the Persian king's legacy, the placement of his burial ground beneath the domed roof universalises his earthly glory.

The cartographical system appearing on the dome adapts ancient and medieval knowledge in image and text. A directly cited sepulchral epigram follows this detailed description, along with a note through which Apelles injects the history of the Jews (as on the gravestone of Stateira): the Old Testament knowledge of the creation of the world, the history of the people of Israel and the Babylonian-Persian succession are once again recounted (serie reuoluta) and dated. In such presentations, many biblical events are exactly measured and related in both spatial and temporal terms. Even though he acts as founder and patron, Alexander is excluded from the biblical knowledge displayed on the sepulchral monument, according to which the third empire has just begun with Alexander's succession from Darius. Medieval readers, however, must have easily grasped the meaning through the textual allusions and their knowledge of the four kingdoms of Daniel. ${ }^{29}$

Alexander's initial intention to ensure the posthumous fame of the Persian King is, however, contradicted by the fact that the name Darius appears nowhere on the gravestone. The epitaph instead verifies the fulfilment of Daniel's prophecy: Alexander receives the epitheton "Hammer of the Whole World", which is said to have destroyed the horns of the buried ram. ${ }^{30}$ The tomb thus does not act primarily as an exhibition space for the deeds of Darius, but as a representation of him as the last ruler of a dynasty terminated by Alexander. Therefore, the function of the monument vacillates between being a grave and a victory monument, designating the historical moment of the translatio imperii and, simultaneously, the climax of Alexander's own life. ${ }^{31}$

The epitomisation of the history of salvation, which gradually unfolds on the gravestones, is a reminder that it is not the worldly fame of a hero that is at the heart of the memorial visualisation, but the hero's role in the course of universal history. Instead of an archaic first-person inscription, Alexander has Apelles create a fantastic sculpture embellished by precious materials for the Persian, which reveals a characteristically medieval aesthetic form. The recipient is no longer led only by the inscription, but also, specifically, by an image sequence. The deictic epitaph, however, provides a key to a hermeneutic infiltration of the art program, which none of the characters within the diegesis are able to understand completely.

29 See Wulfram 2000, 252f.; Lafferty 2011, 137 and Lafferty 1994, 79.

30 See Daniel 8:3-8.

31 See also Lafferty 1994, 81: "At this point in the poem, three books from its conclusion, Alexander has already served his purpose in God's divine plan: once the Persian Empire has fallen, and its power been transferred to the Greeks, Alexander's role in world history is over". 


\section{III}

No romance from the high Middle Ages contains more tombs and epitaphs than the comprehensive anonymous Lancelot-Grail Cycle (1215-1230). The trilogy, called the Prose Lancelot, consists at its core of three parts, Lancelot Propre, Queste del Saint Graal and Mort Artu, which combine courtly, historiographical and religious patterns of narration. In this section, I will argue that tombs in the Prose Lancelot fulfill primarily a narrative function in the entrelacement of the story, and that this function is based both on their materiality and on the prompting nature of their inscriptions. Even though the first complete manuscript of the German Prosa Lancelot dates back to the fifteenth century, it translates the medieval French model quite accurately, so the phenomena discussed in the following section can be considered as exemplary for the medieval Lancelot corpus more generally. ${ }^{32}$

Scholars have pointed out early on that tombs run like a common thread through the narrative world of the Prose Lancelot, unfolding a monumental ensemble to time and space. ${ }^{33}$ The repetition and continuous variation of the tomb motif creates coherence on the discourse-level, ${ }^{34}$ but it might also contribute to the conveyance of meaning on the histoire-level. However, this is complicated both by the tombs' fantastical character, which must have confused contemporary readers accustomed to real world tombs, ${ }^{35}$ and by the mystification which they exert on the protagonists reading them within the narrative. This mystification is based on two characteristics: the fact that tombs always prompt what in Middle High German is referred to as aventiure and the fact that tomb inscriptions are proleptic, prophesying events that will only occur later in the story.

Aventiure is the guiding principle of the Knights of the Round Table. Time after time the heroes set out to prove their strength in competitions and to fight for law and order in the kingdom. They are often confronted with anonymous signs that claim authoritative validity: in addition to letters, signposts and inscribed weapons, tombs are among the objects of the narrative world which promise the knights aventiure, thus motivating the course of action in the story. At each cyclic return to Camelot, Arthur asks the knights to give a detailed report-following the historiographical principle of eyewitness testimony-which is then recorded by learned writers at court. Compared

32 While the first extant complete manuscript of the German Prosa Lancelot, ms. P (cpg 147), dates back to the third quarter of the fifteenth century, only the fragments M (cgm 5250) and A (Amorbacher Pergamentstück) go back to the thirteenth century. We can therefore only state with certainty that there was a German translation of Lancelot Propre in the high Middle Ages.

33 See Solterer 1984, 558.

34 Similarly, Maddox concluded that tombs would act "as a means of increasing the efficiency of its readers memory of a massive work of fiction" (Maddox 2000, 338).

35 Colliot has pointed out that epitaphs in Prosa-Lancelot are formally distinguished from real tomb inscriptions. Instead of limiting themselves to common templates, they are often individually designed. Also, they show no notion of Christian piety. See Colliot 1973, 155. 
with other Arthurian romances, the Prosa Lancelot stresses the significance of literacy, placing reading, writing and interpreting at the centre of the heroic system of trial and triumph.

In Lancelot Propre, tombs not only act as memoria but also prophesise future events. $^{36}$ Therefore, they often feature two epitaphs, one on the outside, which indicates the arrival of a destined knight who alone will be able to open the tomb and thus distinguish himself from all others, and additionally one on the inside, which provides information about the entombed body. The tombs are guarded by characters from the religious world, carriers of historical and legendary knowledge. Sometimes they even "replace" the exterior epitaph by giving instructions to open the graves. However, their main function seems to consist of supervising the grave opening and leading the knight to the correct interpretation of the tomb and corpse. ${ }^{37}$

Lancelot, protagonist of the first part of the romance, succeeds in opening some graves and thereby reveals the prehistory of his own kinship. He gradually discovers the tombs of his ancestors Galaad I and Simeu (son and nephew of Joseph of Arimathea respectively), of his friend Galahot and, finally, of Lancelot I, his grandfather. However, the series of tomb adventures begins with the discovery of his own name, which is hidden under a coffin lid in the cemetery of the Dolorose Garde. ${ }^{38}$ His first adventure profiles not only the thematic nexus of tomb, identity and genealogy, which then determines the grave adventures in Lancelot Propre, but it also demonstrates the deceptive potential of writing by new, unauthorised scribes. When Lancelot arrives at the cemetery of the enchanted castle Dolorose Garde, he spots a tomb that differs from the others because of its material design and enigmatic inscription: ${ }^{39}$

[...] der was groß und schwere und wúnderlich gewurckt mit golde und mit herlichem gesteyn. Er was aller mit buchstabe gemacht, die sprachen: "Dißer sargk enmag nymer von mannes hant off gehaben werden, wedder mit gewalt noch anders, es thú dann der der diße jemerliche burg sol gewinnen und des name ste hieunden geschriben.” (LuGin I, 452, 20-26)

36 Valette's discussion of the relation between prophetic dreams and prophetic tombs points this out particularly. See Valette 1998, 416-424.

37 On this topic see Unzeitig-Herzog 1990.

38 Klinger has interpreted this epitaphic figure of finalisation as a means to emphasise the biographical construction of the romance, see Klinger 2001, 89.

39 Cited after Steinhoff (ed.) 1995-2004, in the following the three parts, Lancelot Propre, Queste del Saint Graal and Mort Artu, are cited as LuGin I/II, LuGral I/II and Suche with page and line references. Reference passages in the French Lancelot en prose as well as the attendant English translation will be added for all quotes. French citations refer to Micha 1978-1983 (given with number of volume in Roman numerals and page number) and Pauphilet 1923 (with page number and line). All English translations are taken from Lacy 2010 (with number of volume and page number). 
In the middle of the graveyard lay a large slab of metal extraordinarily crafted in gold and stones and enamels, which bore words that said, "This slab will never be raised by hand or strength of man, save by the one who will win this woeful castle and whose name is engraved underneath." ${ }^{40}$

The narrator explains that many have already tried with strength and brains to open the coffin lid, above all the lord of the castle, who strongly wishes to find out the name of his last opponent; but so far nobody has succeeded. It remains unclear, though, who might have composed the epitaph. Fearlessly, Lancelot lifts the lid and finds another inscription underneath:

In dißem grab sol Lancelot ligen von dem Lacke, des kóniges Banes son von Bonewig und Alennen synes wibes. "Er leyt den sargk wiedder nyder und wust wol das syn name was den er funden hett." (LuGin I, 454, 4-7)

Then he saw the words that said, "Here will lie Lancelot of the Lake, son of King Ban of Benoic." He let the slab down again, knowing that it was his own name that he had just seen. ${ }^{41}$

Although the epitaph inside the tomb refers to Lancelot as the rescuer of the castle, the spell is still not broken. The lord of the castle has fled and, furthermore, captured an advancing group of knightly heroes of the Round Table. To free the castle, Lancelot must wait forty days or find a magic key. Meanwhile, Arthur and Ginover arrive at the Dolorose Garde, believing it had been liberated. Instead of being received by their entourage as expected, they are frightened by the sight of a number of new inscriptions: citizens of the neighbouring town have overnight secretly re-labelled the tombs with words declaring all Arthur's knights dead-probably in order to incite the king to retaliatory strikes and thus speed up the liberation of the castle. By doing so the citizens create a radical thanatopos that anticipates the final doom of the Knights of the Round Table at the very end of the romance, in the Mort Artu.

The setting of the cemetery alludes to the final Joie de la curt episode in Erec et Enide by Chrétien de Troyes. There, Erec comes across a series of pointed poles in the garden of Mabonagrin, on which the heads of failed knights are impaled. The tomb inscriptions on the cemetery of the Dolorose Garde also refer to the heads of the defeated that are attached on tops of the merlons of the castle wall. However, the cemetery

40 Translation by Lacy 2010, 3, 153. The German text is equivalent to the text available in the French edition, see Micha XXIVa, 30-33, 331: Et el mi lieu de le chimentiere si avoit une grant lame de metal tres merveilleusement ouvree $a$ or et a pieres et a esmax, et si i avoit lettres qui disoient "ceste lame n'iert ja levee par main d'omme ne par esfors, se par chelui non qui conquerra cest doleros castel et de chelui est li nons escris ci desous".

41 Translation by Lacy 2010, 3, 153. The text of the French edition replicates the wording almost exactly. See Micha VII, XXIVa, 32, 332: Et lors voit les lettres qui dient: “Chi gerra Lancelos del Lac, li fiex au roi Ban de Benoÿc." Et lors remet la lame jus et bien seit que ch'est ses nons qu'il a veu. 
not only aims at deterring intruders, but also mirrors the culture of commemoration. Since the memory of the dead cannot be preserved by their transient faces, individually designed epitaphs are minted in robust memorial materials. A cleric accompanies Arthur and reads the epitaphs to him:

[...] "Hie lyt myn herre Gawan, und das ist syn heubt." Er laß off eim andern:"Hie lyt myn herre Ywan, und ist das syn heubt." Er laß off eim andern: "Hie lyt myn herre Ywan, und das ist syn heubt, des großen Friens eins koniges sun." Sie lasen furter allenthalben, und der konig und alle die mit im waren machten den meisten jamer von aller der welt. (LuGin I, 486, 12)

[...] and they went on until they came to a gravestone which bore the name of Sir Gawain and said, "Here lies Gawain and up there is his head.” And other stones said the same of all knights that Gawain had brought with him. ${ }^{42}$

Although the corresponding heads do not belong to his knights, Arthur is overwhelmed by the scene. The manipulated tombs make him believe that his best knights have died and that their return to the Arthurian court has forever been denied. The whole scene undermines the very idea of tombs as reliable stores of memory, instead showing epitaphs as susceptible to deceptive manipulation..$^{43}$ Even though (or perhaps precisely because) they do not refer to their authors, tomb inscriptions always suggest a factuality which can hardly be questioned if the dead lie hidden under their gravestones.

Finally, Lancelot succeeds in breaking the spell of the castle by using a script-bearing magic key. But the uncanny cemetery vision has accurately prefigured the end of the novel: while in the Mort Artu Lancelot is indeed buried at the Dolorose Garde, Arthur arranges a huge burial place in St Stephen's Cathedral in Camelot, not for himself and his spouse but for all the fallen knights and ladies of his kingdom. Moreover, Lancelot's status as the best knight is compromised. After having committed adultery, he is no longer considered suitable for the important search for the Holy Grail recounted in the Queste. With the solemn appointment of his son Galaad on the day of Pentecost, the romance's event structure changes fundamentally: from then on aventiure is only assigned to Galaad and his immaculate companions, while the rest of the Round Table experiences a long uneventful period. Various tombs, such as the voice of the burning tomb of Simeu and the epitaph on the tomb of Corbenic Castle, anticipate this conferral of the protagonist status from Lancelot to Galaad.

This changing event structure is accompanied by a reevaluation of knighthood itself. Galaad's initial aventiure, which is analogous to his father's first adventure in

42 Translation by Lacy 2010, 3, 165. Unlike in the German text, Yvain is not mentioned in the French text. See Micha VII, XXVIIIa.11, 354: [...] et tant qu'il vienent a une tombe ou li nons mon signor Gauvain estoit escris; si i avoit "Chi gist mesire Gauvain et vés la sa test" et autretel dient de tous les compaignons que mesires Gauvain avoit amenés avoec lui.

43 The motif of the false grave, in which writing plays a big part, has existed since antiquity and was popular also in medieval times, as we see in romances like Apollonius of Tyre, Floire et Blancheflor and many more. 
that it also consists of a grave opening, demonstrates this. In a monastery, Galaad is led to the grave of his ancestor Nascien, from which a ghastly voice resonates. The monks predict that he will find a letter (buchstaben) under the tomb slab. ${ }^{44}$ Yet, after having dispelled a devilish figure emerging out of the open sarcophagus, he finds not letters but the body of an armed knight. An old monk teaches him about the allegorical meaning of the adventure. The solidity of the tomb slab stands for the hardness of the world, the corpse for the hardness of the people and the voice for the words of Pontius Pilate. Galaad's aventiure thus acts as a symbol of the advent and passion of Christ, which in turn points to the advent of the redeemer Galaad himself. The missing letters mark a striking turning point: instead of looking for written documents of the past, Galaad is instructed to discern the truth of creation in the pure materiality of things. The episode hints at a semiotic view of the world according to which all created things can be interpreted as signs of divine revelation.

After Galaad has concluded the quest for the Holy Grail, there are no aventiures left for the other knights to endure. Bohort, Galaad's companion, delivers a last eyewitness account after his return from Sarras before Arthur orders the chronicles to be archived in the Royal Abbey at Salisbury. From then on, the cyclical documentation of events at court is replaced by a final biographical monumentalisation in St Stephen's Cathedral: ${ }^{45}$ major and minor characters are placed here one after the other. Lancelot and Arthur are buried separately-most likely because in this way they remain excluded from a collective memoria of moral decline, which actually dominates the image given in the cathedral of Camelot.

Two aspects of the Mort Artu's lieu de mémoire are relevant. First, it continues the Arthurian chronicle by giving detailed descriptions of the tombs and by citing eight epitaphs, converging the narration with historiography. Second, it again features the tombs' potential for deception and the agency of sepulchral inscriptions. King Arthur, wishing to create a collective sepulchral memorial for his own court, unintentionally triggers its demise. Because they leave out the accidental circumstances of the deaths of the deceased, but still name the person who appears to be responsible, the tombs in St Stephen's Cathedral cause hatred and hostility in the courtly society, generating conflict in the story. ${ }^{46}$ For example, Garheiss von Tharahen was killed by an apple given to him accidentally by Ginover, who is then mentioned on his tomb as his murderer. Fräulein von Challot dies out of excessive love for Lancelot, who is named as the cause of her death on her tomb. Such ambiguous epitaphs and many more trigger fatal events after the quest for the Holy Grail has finished. Although they were erected

\footnotetext{
44 Suche, 76, 2f. In the French version there is no letter mentioned. See Pauphilet, 36, 12-14: Or vos dirai donc, fet li freres, que vos feroiz: alez a cele tombe la, et la levez, et je vos di que vos troveroiz desoz aucune grant merveille (Lacy 2010, 6, 24: “'I'll tell you what to do,' the monk continued. 'Go over to the tombstone and lift it. You're certain to find a wondrous surprise underneath'.”).

45 See Waltenberger 1990, 154; Wandhoff 2003, 322; Klinger 2011, 442; Witthöft 2014, 248. 46 See Witthöft 2014.
} 
without fraudulent intent, they invoke further battles and violence among the members of Arthur's court. In a world without aventiure, the Arthurian society itself brings back "eventfulness" by unleashing fatal entanglements through the public exhibition of tomb inscriptions.

\section{IV}

All three of my examples display the notion that the medial and material design of tombs can contribute to evoking the past in the present. While tombs are cited in historiography in order to provide historical evidence and to preserve the memory of the deceased, literary texts use them to reflect on the relation between the individual and universal time, between personal identity and kinship and on the connection between past, present and future. The three texts use different medial and material techniques to highlight the tomb passages.

Orderic Vitalis dedicates a large portion of his history of the contemporary present to honouring the deceased of his own time. The number of epitaphs, which he cites verbatim and in their entirety, create rhythmic and typographic disruptions of his text, rendering the insertions audible and visible for the reader. Furthermore, Orderic describes the materiality and the spatial arrangement of the gravestones meticulously, which fosters historical authenticity. While he aims at visualising certain places, the indications in the layout and the change from prose to verse invite the reader to retrospectively become part of the commemoration.

The second example, the Alexandreis, is affiliated with the classical epic tradition. In the Middle Ages, the conquest of Alexander is not only relevant historically, but also relates to the history of salvation. Tombs here exhibit the transition of the empires and function as chronotopic spaces in which the heroic age is related to universal history. The final epitaph on Darius's tomb, which Alexander has endowed, is generally directed towards every reader, but its meaning only becomes accessible to those recipients with knowledge of the history of salvation, such as the medieval readers of the Alexandreis.

In the Prosa Lancelot the tomb motif is integrated into overlapping courtly, historical and religious patterns of narration. Due to their enigmatic character, tombs attract knights errant looking for aventiure, but only Lancelot is capable of opening some of the graves, where he finds the bodies of his ancestors. In order to connect Lancelot to his origins, the metonymic principle of representing the deceased via signs and materiality seems oddly insufficient. It is superseded by the autoptic principle of first-hand-encounter with the dead. In the finale of the romance, this wariness towards the ability of sepulchral representation itself resonates in the repeated misinterpretations of epitaphs, which lead to the collapse of the Arthurian court. 


\section{Works Cited}

\section{Primary Sources}

Galterus de Castellione (1978), Alexandreis, ed. by Marvin L. Colker (Thesaurus Mundi 17), Padua. Lancelot-Grail. The Old French Arthurian Vulgate and Post-Vulgate in Translation (2010²), ed. by Norris J. Lacy, 10 vols., Woodbridge.

Lancelot. Roman en prose du XIII' siècle (1978-1983), ed. with introd. and notes by Alexandre Micha, 9 vols. (Textes littéraires français), Geneva.

Orderic Vitalis, The Ecclesiastical History (1980), ed., trans., with introd. and notes by Marjorie Chibnall, 6 vols., Oxford.

Orderic Vitalis, Historia Ecclesiastica IV MS lat. 5506, vol. 2, fol. 99, <https://gallica.bnf.fr/ ark:/12148/btv1b100321460/f100.item> (last accessed: 30.05.2019).

Prosalancelot. Nach der Heidelberger Handschrift Cod. Pal. germ. 147 (1995-2004), ed., trans., with notes by Hans-Hugo Steinhoff, 5 vols. (Bibliothek Deutscher Klassiker, Bibliothek des Mittelalters 14-18), Frankfurt am Main.

La Queste del Saint Graal. Roman du XIII' siècle (1923), ed. by Albert Pauphilet (Les classiques français du Moyen Âge 33), Paris.

Recueil des rouleaux des morts (2005-2008), ed. by Jean Favier and Jean Dufour, 4 vols. (Recueil des historiens de la France: Obituaires), Paris.

Walter of Châtillon (1996), Alexandreis. A Twelfth-Century Epic, trans. by David Townsend, Philadelphia.

\section{Secondary Sources}

Ariès, Philippe (2009 $\left.{ }^{12}\right)$, Geschichte des Todes. Aus dem Französischen von Hans-Horst Henschen, Munich.

Bauch, Kurt (1976), Das mittelalterliche Grabbild. Figürliche Grabmäler des 11. bis 15. Jahrhunderts in Europa, Berlin.

Castelain, Georges (2016), “Les Épitaphes d'Hector et d'Achille. Funktion und Gestaltung einer 'Geschichtskorrektur”, in: Tobias Leuker (ed.), Vom Adamsspiel bis Jodelle. Theologische und humanistische Gelehrsamkeit im frühen französischen Theater (Beihefte zum Archiv für Kulturgeschichte 78), Cologne/Weimar/Vienna 2016, 109-130.

Colliot, Regine (1973), “Les epitaphes arthuriennes”, in: Bibliographical Bulletin of the International Arthurian Society XXV, 155-175.

Debiais, Vincent/Ingrand-Varenne, Estelle (2016), “Inscriptions in Orderic's Historia ecclesiastica. A Writing Technique between History and Poetry”, in: Charles Rozier, Daniel Roach, Giles E. M. Gasper and Elisabeth van Houts (eds.), Orderic Vitalis. Life, Works and Interpretations. Woodbridge, 127-144.

Dufour, Jean (ed.) (2005-2013), Recueil des rouleaux des morts (VIIle siècle-vers 1536), 5 vols. (Recueil des historiens de la France. Obituaires. Série in- $4^{\circ}, 8$ ), Paris.

Kay, William (2013), Living Stones. The Practice of Remembrance at Lincoln Cathedral (1092-1235), St Andrews, <http://hdl.handle.net/10023/4463> (last accessed: 30.05.2019).

Killermann, Corinna (2002), "Die mittelalterliche Kommentierung der Alexandreis Walters von Châtillon als Fall impliziter antik-mittelalterlicher Dependenz und Selbstkonstituierung", in: Jan Cölln, Susanne Friede and Hartmut Wulfram (eds.), Alexanderdichtung im Mittelalter. Kulturelle Selbstbestimmung im Kontext literarischer Beziehungen (Veröffentlichung aus dem Göttinger 
Sonderforschungsbereich 529 “Internationalität nationaler Literaturen”. Serie A: Literatur und Kulturräume im Mittelalter 2), Göttingen, 299-331.

Klinger, Judith (2011), Der mißratene Ritter. Konzeptionen von Identität im Prosa-Lancelot (Forschungen zur Geschichte der älteren deutschen Literatur 26), Munich.

Kloos, Rudolf M. (1980), Einführung in die Epigraphik des Mittelalters und der frühen Neuzeit, Darmstadt.

Körner, Hans (1997), Grabmonumente des Mittelalters, Darmstadt.

Lafferty, Maura K. (1994) “Mapping Human Limitations. The Tomb Ecphrases in Walter of Châtillon's Alexandreis", in: The Journal of Medieval Latin 4 (1), 64-81.

Lafferty, Maura K. (2011), “Walter of Châtillons Alexandreis”, in: David Zuwiyya (ed.), A Companion to Alexander Literature in the Middle Ages (Brill's Companions to the Christian Tradition 29), Leiden/Boston, 177-200.

Maddox, Donald (2000), “'A Tombeau ouvert'. Memory and Mortuary Monuments in the Prose Lancelot”, in: Keith Busby and Catherine M. Jones (eds.), 'Por le soie amisté'. Essays in Honor of Norris J. Lacy, Amsterdam/Atlanta, 323-338.

Newstok, Scott L. (2009), Quoting Death in Early Modern England. The Poetics of Epitaphs Beyond the Tomb, Basingstoke.

Panofsky, Erwin (1964), Grabplastik. Vier Vorlesungen über ihren Bedeutungswandel von AltÄgypten bis Bernini, ed. by Horst W. Janson, Cologne.

Petrucci, Armando (1995), Le scritture ultime. Ideologia della morte e strategie dello scrivere nella tradizione occidentale, Turin.

Pohl, Benjamin (2015): Dudo of Saint Quentin's Historia Normannorum. Tradition, Innovation and Memory (Writing history in the Middle Ages), Martlesham.

Ratkowitsch, Christine (1991), Descriptio Picturae. Die Literarische Funktion der Beschreibung von Kunstwerken in der lateinischen Großdichtung des 12. Jahrhunderts (Wiener Studien: Beiheft 15), Vienna.

Signori, Gabriela (2014), “Introduction. The Rotulus”, in: Hartmut Beyer, Gabriela Signori and Sita Steckel (eds.), Bruno the Carthusian and his Mortuary Roll. Studies, Text, and Translation (Europa Sacra 16), Turnhout, 3-10.

Solterer, Helen (1984), “Conter le terme de cest brief. L'inscription dans La Mort le Roi Artu”, in Charles Foulon (ed.), Actes du 14 e Congrès international arthurien. Rennes, 16-21 août 1984, Rennes, 558-568.

Svenbro, Jasper (1988), Phrasikleia. Anthropologie de la lecture en Grèce ancienne (Textes à l'appui: Histoire classique), Paris.

Unzeitig-Herzog, Monika (1990), Jungfrauen und Einsiedler. Studien zur Organisation der Aventiurewelt im Prosalancelot (Beiträge zur älteren Literaturgeschichte), Heidelberg.

Valette, Jean-René (1998), La poétique du merveilleux dans le Lancelot en prose, Paris.

Waltenberger, Michael (1990), Das große Herz der Erzählung. Studien zur Narration und Interdiskursivität im 'Prosa-Lancelot' (Mikrokosmos 51), Frankfurt am Main.

Wandhoff, Haiko (2003), Ekphrasis. Kunstbeschreibungen und virtuelle Räume in der Literatur des Mittelalters (Trends in Medieval Philology 3), Berlin/New York.

Witthöft, Christiane (2014), "Finalität. Grabinschriften in der Untergangserzählung des Prosalancelot”, in: Udo Friedrich, Andreas Hammer and Christiane Witthöft (eds.), Anfang und Ende. Formen narrativer Zeitmodellierung in der Vormoderne, Berlin, 243-265.

Wulfram, Hartmut (2000), "Explizite Selbstkonstituierung in der Alexandreis Walters von Châtillon”, in: Jan Cölln, Susanne Friede and Hartmut Wulfram (eds.), Alexanderdichtung im Mittelalter. Kulturelle Selbstbestimmung im Kontext literarischer Beziehungen (Veröffentlichung aus dem Göttinger Sonderforschungsbereich 529 “Internationalität nationaler Literaturen”: Serie A: Literatur und Kulturräume im Mittelalter 1), Göttingen, 299-331. 